\title{
Cardiovascular Risk Factors and Knowledge of Symptoms Among Vietnamese Americans
}

\author{
Tung T. Nguyen, $M D^{7}$, Youlian Liao, $M D^{2}$, Ginny Gildengorin, $P h D^{7}$, Janice Tsoh, $P h D^{3}$, \\ Ngoc Bui-Tong, MHA ${ }^{4}$, and Stephen J. McPhee, $M D^{7}$
}

'Vietnamese Community Health Promotion Project, Division of General Internal Medicine, Department of Medicine, University of California, San Francisco, CA, USA; ${ }^{2}$ National Center for Chronic Disease Prevention and Health Promotion, Centers for Disease Control and Prevention, Atlanta, GA, USA; ${ }^{3}$ Department of Psychiatry, University of California, San Francisco, USA; ${ }^{4}$ Santa Clara Valley Health and Hospital System, San Jose, CA, USA.

BACKGROUND: There are few population-based studies of cardiovascular risk factors, knowledge, and related behaviors among Vietnamese Americans.

OBJECTIVE: To describe cardiovascular risk factors, knowledge, and related behaviors among Vietnamese Americans and compare the results to non-Hispanic whites.

DESIGN: Comparison of data from two populationbased, cross-sectional telephone surveys.

PARTICIPANTS: Vietnamese Americans in Santa Clara County, California, and non-Hispanic whites in California, aged 18 and older.

MEASUREMENTS: Survey measures included sociodemographics, diagnoses, body mass index, fruit and vegetable intake, exercise, and tobacco use. Knowledge of symptoms of heart attack and stroke was collected for Vietnamese Americans.

MAIN RESULTS: Compared to non-Hispanic whites (n= 19,324), Vietnamese Americans ( $n=4,254)$ reported lower prevalences of obesity, diabetes mellitus, coronary heart disease, and hypertension, and similar prevalences of stroke and hypercholesterolemia. Fewer Vietnamese Americans consumed fruits and vegetables five or more times daily $(27.8 \%$ vs $16.3 \%, p<0.05)$, and more reported no moderate or vigorous physical activity (12.1\% vs $40.1 \%, p<0.05)$. More Vietnamese men than non-Hispanic White men were current smokers $(29.8 \%$ vs $19.0 \%, p<0.05)$. Vietnamese Americans who spoke Vietnamese were more likely than those who spoke English to eat fruits and vegetables less frequently, engage in no moderate or vigorous physical activity, and, among men, be current smokers. Only 59\% of Vietnamese Americans knew that chest pain was a symptom of heart attack.

CONCLUSIONS: There are significant disparities in risk factors and knowledge of symptoms of cardiovascular diseases among Vietnamese Americans. Culturally ap-

Received April 4, 2008

Revised September 3, 2008

Accepted December 2, 2008

Published online December 17, 2008 propriate studies and interventions are needed to understand and to reduce these disparities.

KEY WORDS: Vietnamese; Asian; cardiovascular disease; epidemiology; disparities.

J Gen Intern Med 24(2):238-43

DOI: $10.1007 / \mathrm{s} 11606-008-0889-1$

(c) Society of General Internal Medicine 2008

\section{INTRODUCTION}

Vietnamese Americans constitute the second fastest growing Asian subgroup in the US. ${ }^{1}$ In 2004 , this population exceeded 1.25 million, with nearly half living in California. ${ }^{2}$ Most are foreign-born, and a majority (55\%) have limited English proficiency. $^{2}$ Vietnamese Americans have low educational attainment, high unemployment, and low self-rated health. ${ }^{3-12}$ They have marked health disparities, including the highest cervical and liver cancer incidence rates of any ethnic groups. ${ }^{13,14}$ Limited access to health care, traditional health beliefs, lack of knowledge about health, and impaired physicianpatient communication are important health-related barriers faced by this population. ${ }^{8}$

Among Asian Americans and Pacific Islanders, heart disease and stroke (i.e., cardiovascular diseases) are the second and third most common causes of death, respectively, ${ }^{15}$ and the incidence rates for these diseases have been rising for some Asian subgroups. ${ }^{16,17}$ In general, there is a lack of data on cardiovascular diseases for Asian-American subgroups. In 1992, data from the California Behavioral Risk Factor Surveillance System (BRFSS) showed that fewer Vietnamese had a cholesterol test compared with the general population. ${ }^{3}$ More recent studies of Vietnamese Americans have reported a high prevalence of hypertension, low levels of exercise, and knowledge about cardiovascular diseases and their risk factors, but they have been limited by the use of convenience sampling. ${ }^{18-20}$ Some population-based studies have described high prevalence of tobacco use among Vietnamese American men. ${ }^{21,22}$ This study differs from prior published studies in that it is a population-based study with a sufficient sample size to provide reliable population-based estimates of cardiovascular disease prevalence, risk factors, knowledge, and related behaviors among Vietnamese Americans and in that it compares these results to a similar survey of non-Hispanic whites. 


\section{METHODS}

\section{Data Source}

As part of the Racial and Ethnic Approaches to Community Health (REACH) 2010 program, the Centers for Disease Control and Prevention conducted annual telephone surveys (REACH 2010 Risk Factor Survey) from 2002 through 2005 among Vietnamese residents of Santa Clara County, California. ${ }^{23-25}$ Because the Vietnamese constituted a small proportion of the total population, a targeted list sample design was used. Households were contacted at random from a list of telephone numbers bearing common Vietnamese surnames, compiled from area telephone directory listings. Each household was screened to ascertain racial and geographic eligibility. All eligible females aged 40-64 years and up to two other household members of either sex aged 18 or older were selected for interview. Trained bilingual interviewers conducted the surveys (70.5\% in Vietnamese and 29.5\% in English). The average cooperation rate for the four annual surveys was $62 \%$ for the household screening interview and $64 \%$ for the household member interview.

The BRFSS is an ongoing, state-based, annual telephone survey of the civilian, non-institutionalized US population. ${ }^{26}$ Only one person aged 18 years and older per household is randomly selected for interview. The surveys are conducted in English and Spanish. Not all BRFSS modules were included each year that the survey was administered. The average response (screening completion) rate was $66 \%$ for households contacted and $75 \%$ (cooperation rate) for household members interviewed during the four annual surveys. For comparison purposes, we report data from the California BRFSS for English-speaking non-Hispanic whites only. Questions used in the REACH 2010 Risk Factor Survey were taken from the questionnaires in BRFSS. Variable definitions were identical in the two surveys. The Institutional Review Board (IRB) of the Centers for Disease Control and Prevention approved the REACH 2010 survey, while the IRB for the State of California Department of Public Health approved the California BRFSS.

\section{Data Collected}

Sociodemographic questions included age, sex, education level, employment, annual household income, and primary spoken language (Vietnamese or English).

Cardiovascular Diseases and Risk Factors. The respondents reported whether they had been diagnosed with diabetes mellitus, hypertension, hypercholesterolemia, coronary heart disease (including heart attack and angina), or stroke. Respondents with hypertension were asked whether they took blood pressure medications. Risk factors included smoking status and body mass index (BMI) (calculated based on self-report of weight and height), which was categorized as normal $\left(<25 \mathrm{~kg} / \mathrm{m}^{2}\right)$, overweight $\left(\geq 25 \mathrm{~kg} / \mathrm{m}^{2}\right.$ but $\left.<30 \mathrm{~kg} / \mathrm{m}^{2}\right)$, and obese $\left(\geq 30 \mathrm{~kg} / \mathrm{m}^{2}\right)$.

Diet was assessed using six items asking the number of times each day that respondents consumed fruit juice, fruit, salad, potatoes, carrots, and the number of servings of other vegetables. Serving size was not defined. For physical activity, respondents were asked to recall their overall frequency and duration of time spent in moderate activities (e.g., brisk walking, bicycling, vacuuming, or gardening) and in vigorous activities (e.g., running, aerobics, or heavy yard work) during a typical week. Respondents were categorized as (1) meeting physical activity recommendations (30 min or more of moderate physical activity at least 5 days a week or 20 min or more of vigorous physical activity at least 3 days a week), (2) performing some moderate or vigorous physical activities, but did not meet recommendations, and (3) performing no moderate or vigorous physical activity. ${ }^{27}$

Knowledge of Symptoms. Vietnamese respondents were asked five questions about whether the following were symptoms of heart attack: (1) pain or discomfort in the jaw, neck, or back; (2) feeling weak, lightheaded, or faint; (3) chest pain or discomfort; (4) pain or discomfort in the arms or shoulder; (5) shortness of breath. An incorrect symptom (sudden trouble seeing in one or both eyes) was included to assess the possibility that a respondent would answer "yes" to all items in a series of closed-ended questions. The respondents also were asked five questions about whether the following were symptoms of stroke: (1) sudden confusion or trouble speaking; (2) sudden numbness or weakness of the face, arm, or leg, especially on one side; (3) sudden trouble seeing in one or both eyes; (4) sudden trouble walking, dizziness, or loss of balance; (5) severe headache without known cause. An incorrect symptom (sudden chest pain or discomfort) was also included. We also asked, "if you thought someone was having a heart attack or a stroke, what is the first thing you would do?" The correct response was to call 911. A person was considered as having correct knowledge of heart attack symptoms and action if he or she correctly answered "yes" to all five questions on symptoms of heart attack, "no" to the incorrect symptom, and "call 911" when he/she thought someone was having a heart attack. ${ }^{28}$ Correct knowledge of stroke symptoms and action was defined similarly.

Analyses. The data analyses plans were approved by the IRB at the University of California, San Francisco. Data on Vietnamese Americans from the 2002 through $2005 \mathrm{REACH}$ 2010 survey were combined in the analysis. In the California BRFSS, data on socio-demographics and general health were collected annually from 2002 through 2005. However, some information was available in selected years only-for example, daily fruit and vegetable intake (2002, 2003, and 2005); physical activity, prevalence of hypertension, cholesterol checked, and hypercholesterolemia (2003 and 2005); and prevalence of cardiovascular diseases (2005). Prevalence estimates were age-standardized for diabetes mellitus, stroke, coronary heart disease, hypertension, cholesterol screening, hypercholesterolemia, BMI, physical activity, diet, and smoking measures. The age distribution of the year 2000 US population was used as the standard (five age groups: 18-34, 35-44, 45-54, 55-64, and 65 years and older). Chi-square test was used to compare prevalences in Vietnamese and in nonHispanic whites and prevalences in Vietnamese-speaking Vietnamese and English-speaking Vietnamese. All analyses were conducted using SUDAAN ${ }^{\circledR}$ to account for the complex sampling designs in REACH 2010 and BRFSS (e.g., combining data from multiple years, stratification, clustering, and sampling weight). 


\section{RESULTS}

Table 1 shows the sociodemographic characteristics of 4,254 Vietnamese and 19,324 non-Hispanic White respondents. Vietnamese Americans were older, more likely to have lower educational attainment, less likely to be employed, and more likely to report an annual household income less than $\$ 25,000$ (all $p<0.05$ ).

Cardiovascular diseases, health behaviors, and risk factors are presented in Table 2. The age-standardized prevalence of diabetes mellitus, coronary heart disease, and hypertension were lower among Vietnamese Americans than among nonHispanic whites. The differences were small but statistically significant $(\mathrm{p}<0.05)$. Vietnamese Americans with hypertension were more likely to take blood pressure medications compared to non-Hispanic whites. Both groups had similar prevalence of stroke and hypercholesterolemia. Obesity was rare among Vietnamese Americans (2.1\% with BMI $\left.\geq 30 \mathrm{~kg} / \mathrm{m}^{2}\right)$.

Compared to non-Hispanic whites, Vietnamese Americans were less likely to eat fruits and vegetables five or more times daily $(16.3 \%$ vs $27.8 \%, \mathrm{p}<0.05)$ or to engage in moderate or vigorous physical activity $(40.1 \%$ vs $12.1 \%$, p<0.05). Among men, Vietnamese Americans were more likely than non-Hispanic whites to be current smokers (29.8\% vs $19.0 \%$, p<0.05).

The age-adjusted prevalence of diabetes mellitus was higher among Vietnamese Americans who responded in the Vietnamese language than among those who responded in English (5.6\% vs $3.5 \%, \mathrm{p}<0.05)$, while the prevalences of coronary heart disease, stroke, hypertension, and hypercholesterolemia were similar. Vietnamese speakers were less likely than those who responded in English to consume more fruits and vegetables and to meet physical activity recommendations (all $\mathrm{p}<0.05$ ) (Table 3). Vietnamese-speaking men were more likely

\section{Table 1. Sociodemographic Characteristics among Vietnamese Americans in Santa Clara County, California, and non-Hispanic whites in California (2002-2005)}

\begin{tabular}{lll}
\hline \hline & $\begin{array}{l}\text { Vietnamese } \\
(\mathrm{N}=4,254) \% \\
(95 \% \mathrm{Cl})\end{array}$ & $\begin{array}{l}\text { Non-Hispanic whites } \\
(\mathrm{N}=19,324) \% \\
(95 \% \mathrm{Cl})\end{array}$ \\
& & \\
& & \\
\hline Age (years)* & $26.7(25.1,28.3)$ & $33.9(33.1,34.8)$ \\
18-34 & $43.8(42.2,45.4)$ & $39.5(38.7,40.4)$ \\
35-54 & $29.5(28.0,30.9)$ & $26.5(25.8,27.3)$ \\
55+ & & \\
Sex & $48.9(47.2,50.6)$ & $49.3(48.4,50.2)$ \\
Male & & \\
Education* & $28.7(27.2,30.1)$ & $17.2(16.4,18.0)$ \\
Less than high school & $25.3(23.8,26.7)$ & $23.6(22.8,24.4)$ \\
High school graduate & $46.0(44.4,47.7)$ & $59.1(58.2,60.1)$ \\
Some college or higher & & \\
Employment* & $45.7(44.1,47.4)$ & $51.1(50.2,52.0)$ \\
Employed & $4.3(3.7,5.0)$ & $9.7(9.3,10.2)$ \\
Self-employed & $13.3(12.2,14.5)$ & $6.6(6.1,7.0)$ \\
Out of work & $27.3(25.9,28.8)$ & $27.8(27.0,28.6)$ \\
Homemaker/student/retired & $9.4(8.5,10.3)$ & $4.8(4.4,5.2)$ \\
Unable to Work & & \\
Annual household income* & $43.9(42.2,45.5)$ & $29.5(28.7,30.4)$ \\
$<$ \$25,000 & $22.3(20.7,23.5)$ & $23.2(22.5,24.0)$ \\
\$25,000 to <\$50,000 & $21.6(20.2,23.0)$ & $38.8(38.0,39.6)$ \\
$\geq \$ 50,000$ & $12.4(11.3,13.5)$ & $8.4(7.9,8.9)$ \\
Unknown & &
\end{tabular}

$C I=$ confidence interval; ${ }^{*} p<0.05$ comparing Vietnamese and nonHispanic whites.
Table 2. Cardiovascular Diseases and Risk Factors Among Vietnamese Americans in Santa Clara County, California, and Non-Hispanic Whites in California (2002-2005)

\begin{tabular}{|c|c|c|}
\hline & $\begin{array}{l}\text { Vietnamese \% } \\
(95 \% \mathrm{Cl})\end{array}$ & $\begin{array}{l}\text { Non-Hispanic } \\
\text { whites \% } \\
(95 \% \mathrm{Cl})\end{array}$ \\
\hline \multicolumn{3}{|l|}{ History of Diseases and Treatment } \\
\hline Diabetes mellitus*† & $5.3(4.7,6.0)$ & $7.3(6.8,7.8)$ \\
\hline Stroke $^{\dagger}$ & $2.3(1.5,3.4)$ & $2.5(2.0,3.0)$ \\
\hline Coronary heart disease ${ }^{*}$ & $3.1(2.3,4.3)$ & $5.7(5.0,6.4)$ \\
\hline Hypertension* ${ }^{\dagger}$ & $22.4(21.2,23.6)$ & $24.5(23.6,25.4)$ \\
\hline $\begin{array}{l}\text { Taking blood pressure } \\
\text { medication if has hypertension* }\end{array}$ & $75.2(72.1,77.9)$ & $65.5(63.1,67.8)$ \\
\hline Ever had cholesterol checked ${ }^{\dagger}$ & $73.0(71.4,74.6)$ & $74.4(73.3,75.5)$ \\
\hline $\begin{array}{l}\text { Has high cholesterol if has } \\
\text { cholesterol checked }^{+}\end{array}$ & $30.2(28.6,31.9)$ & $30.7(29.5,32.0)$ \\
\hline \multicolumn{3}{|l|}{ Risk Factors } \\
\hline \multicolumn{3}{|l|}{ Body mass index* ${ }^{\dagger}$} \\
\hline Normal $\left(<25 \mathrm{~kg} / \mathrm{m}^{2}\right)$ & $80.6(79.2,82.0)$ & $41.0(40.2,41.9)$ \\
\hline Overweight $\left(25-<30 \mathrm{~kg} / \mathrm{m}^{2}\right)$ & $17.3(16.0,18.7)$ & $37.3(36.4,38.2)$ \\
\hline Obese $\left(\geq 30 \mathrm{~kg} / \mathrm{m}^{2}\right)$ & $2.1(1.6,2.7)$ & $21.7(20.9,22.4)$ \\
\hline \multicolumn{3}{|l|}{ 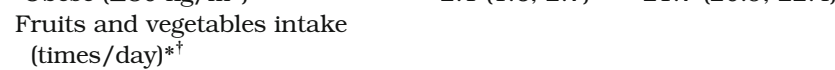 } \\
\hline None & $5.5(4.8,6.4)$ & $4.9(4.5,5.4)$ \\
\hline 1 or 2 & $42.9(41.2,44.7)$ & $33.9(33.0,34.9)$ \\
\hline 3 or 4 & $35.2(33.6,36.9)$ & $33.3(32.4,34.3)$ \\
\hline 5 or more & $16.3(15.1,17.6)$ & $27.8(26.9,28.8)$ \\
\hline \multicolumn{3}{|l|}{ Physical activity* } \\
\hline Meets recommendation & $22.7(21.2,24.2)$ & $33.7(32.5,34.9)$ \\
\hline $\begin{array}{l}\text { Some activity but did not meet } \\
\text { recommendation }\end{array}$ & $37.2(35.5,38.9)$ & $54.2(53.0,55.5)$ \\
\hline No moderate or vigorous activity & $40.1(38.4,41.8)$ & $12.1(11.3,13.0)$ \\
\hline \multicolumn{3}{|l|}{ Smoking status, men*t } \\
\hline Current & $29.8(27.5,32.3)$ & $19.0(17.9,20.1)$ \\
\hline Former & $19.3(17.5,21.2)$ & $28.5(27.4,29.6)$ \\
\hline Never & $50.9(48.3,53.5)$ & $52.5(51.2,53.9)$ \\
\hline \multicolumn{3}{|l|}{ Smoking status, women*† } \\
\hline Current & $1.1(0.7,1.7)$ & $12.3(11.5,13.0)$ \\
\hline Former & $1.1(0.7,1.7)$ & $20.4(19.6,21.2)$ \\
\hline Never & $97.8(97.0,98.4)$ & $67.4(66.3,68.4)$ \\
\hline
\end{tabular}

Not all variables were available for all four years in Non-Hispanic Whites (See Method). $C I=$ confidence interval; * $p<0.05$ comparing Vietnamese and Non-Hispanic Whites; ${ }^{\dagger}$ Age-standardized.

to be current smokers than English-speaking Vietnamese men (31.4\% vs 28.1\%, p<0.05). Although English-speaking Vietnamese women were more likely to be current smokers $(1.5 \%$ vs $0.8 \%, \mathrm{p}<0.05$ ) and Vietnamese-speaking women were more likely to be past smokers ( $1.3 \%$ vs $0.4 \%, \mathrm{p}<0.05$ ), $98 \%$ of the Vietnamese women, regardless of the language they spoke, were never smokers.

There was no significant difference in the knowledge of symptoms of heart attack and stroke between Vietnamesespeaking and English-speaking Vietnamese Americans (Table 3). Most Vietnamese Americans (85\%) knew that they should "call 911" if they had a heart attack or stroke, but only $59 \%$ knew that chest pain was a symptom of heart attack, and only $67 \%$ knew that sudden numbness or weakness of the face, arms, or legs was a symptom of stroke. Only $5 \%$ and $22 \%$ of Vietnamese Americans could identify all five correct symptoms for heart attack or stroke, respectively. Less than $1 \%$ and $5 \%$ of Vietnamese Americans had the correct knowledge of symptoms and action (five correct symptoms, one incorrect symptom, and "call 911") for heart attack and strokes, respectively. 
Table 3. Cardiovascular Risk Factors, Knowledge, and Related Health Behaviors Among Vietnamese- speaking and Englishspeaking Vietnamese in Santa Clara County, California (2002-2005)

\begin{tabular}{|c|c|c|}
\hline & $\begin{array}{l}\text { Vietnamese- } \\
\text { speaking } \\
(\mathrm{N}=3,068) \% \\
(95 \% \mathrm{Cl})\end{array}$ & $\begin{array}{l}\text { English- } \\
\text { Speaking } \\
(\mathrm{N}=1,186) \% \\
(95 \% \mathrm{Cl})\end{array}$ \\
\hline \multicolumn{3}{|l|}{ Risk Factors } \\
\hline \multicolumn{3}{|l|}{ Body mass index } \\
\hline Normal $\left(<25 \mathrm{~kg} / \mathrm{m}^{2}\right)$ & $80.8(79.1,82.4)$ & $80.6(77.7,83.2)$ \\
\hline Overweight $\left(25-<30 \mathrm{~kg} / \mathrm{m}^{2}\right)$ & $17.3(15.8,19.0)$ & $17.1(14.6,19.8)$ \\
\hline Obese $\left(\geq 30 \mathrm{~kg} / \mathrm{m}^{2}\right)$ & $1.9(1.4,2.6)$ & $2.3(1.5,3.5)$ \\
\hline \multicolumn{3}{|l|}{$\begin{array}{l}\text { Fruits and vegetables intake } \\
\text { (times/day)* }\end{array}$} \\
\hline None & $5.2(4.3,6.3)$ & $5.9(4.4,7.9)$ \\
\hline 1 or 2 & $45.9(43.7,48.0)$ & $35.9(32.7,39.2)$ \\
\hline 3 or 4 & $34.0(32.0,36.1)$ & $38.3(35.0,41.7)$ \\
\hline 5 or more & $14.9(13.4,16.5)$ & $19.9(17.3,22.7)$ \\
\hline \multicolumn{3}{|l|}{ Physical activity* } \\
\hline Meets recommendation & $21.3(19.6,23.1)$ & $25.4(22.5,28.6)$ \\
\hline $\begin{array}{l}\text { Some activity but did not meet } \\
\text { recommendation }\end{array}$ & $35.9(33.8,38.0)$ & $39.1(35.8,42.4)$ \\
\hline No moderate or vigorous activity & $42.8(40.7,45.0)$ & $35.5(32.3,38.9)$ \\
\hline \multicolumn{3}{|l|}{ Smoking status, men* } \\
\hline Current & $31.4(28.5,34.5)$ & $28.1(23.8,32.8)$ \\
\hline Former & $20.9(18.7,23.3)$ & $14.5(11.5,18.2)$ \\
\hline Never & $47.7(44.5,50.9)$ & $57.4(52.4,62.2)$ \\
\hline \multicolumn{3}{|l|}{ Smoking status, women* } \\
\hline Current & $0.8(0.4,1.5)$ & $1.5(0.8,3.0)$ \\
\hline Former & $1.3(0.8,2.0)$ & $0.4(0.1,1.4)$ \\
\hline Never & $98.0(97.0,98.6)$ & $98.0(96.5,98.9)$ \\
\hline \multicolumn{3}{|l|}{ Knowledge } \\
\hline $\begin{array}{l}\text { Knew to call } 911 \text { if have a heart } \\
\text { attack or stroke }\end{array}$ & $84.2(82.6,85.7)$ & $86.1(83.4,88.4)$ \\
\hline $\begin{array}{l}\text { Knew chest pain is a symptom of } \\
\text { heart attack }\end{array}$ & $57.8(55.6,59.9)$ & $60.1(56.7,63.3)$ \\
\hline $\begin{array}{l}\text { Knew sudden numbness or } \\
\text { weakness is a symptom } \\
\text { of stroke }\end{array}$ & $66.0(64.0,68.0)$ & $69.0(65.7,72.1)$ \\
\hline $\begin{array}{l}\text { Correct knowledge of heart } \\
\text { attack symptoms and action }\end{array}$ & $0.6(0.3,1.1)$ & $1.2(0.7,2.0)$ \\
\hline $\begin{array}{l}\text { Correct knowledge of stroke } \\
\text { symptoms and action }\end{array}$ & $4.2(3.4,5.1)$ & $4.0(3.0,5.4)$ \\
\hline
\end{tabular}

All values are age-standardized. $C I=$ confidence interval; ${ }^{*} p<0.05$ comparing Vietnamese- and English- Speaking Vietnamese Americans.

\section{DISCUSSION}

To our knowledge, this is the first in-depth report of a population-based survey of cardiovascular risk factors and knowledge of symptoms of heart attack and stroke among Vietnamese Americans. Compared with non-Hispanic whites in California, Vietnamese Americans reported lower prevalences of obesity, diabetes mellitus, coronary heart disease, and hypertension, similar prevalences of hypercholesterolemia and stroke, lower frequency of fruit and vegetable intake, and higher rates of physical inactivity and, among men, cigarette smoking. Among Vietnamese Americans, those who responded in the Vietnamese language were more likely to eat fruits and vegetables less frequently on a daily basis, engage in no moderate or vigorous physical activity, and, among men, be current smokers.

Some studies have reported that Asians suffer from obesityrelated problems at a lower BMI cutoff than the usual standards. $^{29,30}$ In this study, compared to non-Hispanic whites, Vietnamese Americans had a much lower prevalence of obesity, but a similar prevalence of hypercholesterolemia and only slightly lower prevalences of diabetes mellitus and hypertension. Higher BMI has been shown to be associated with US birthplace in Asian-American populations. ${ }^{31}$ We did not measure birthplace, but there was no difference in BMI between Vietnamese Americans who responded in Vietnamese or in English.

Physical inactivity is an important cardiovascular risk factor, and $40 \%$ of Vietnamese Americans, compared to $12 \%$ of non-Hispanic whites, did not engage in any moderate or vigorous activity. Physical activity measures in this study included walking, gardening, and other activities that raise the heart rate, as well as typical exercise, such as running. Thus, cultural differences in activities that constitute exercise are unlikely explanations for this difference. Little has been published about how Vietnamese Americans view exercise or what type of activity would engage them. We did find here that those who spoke Vietnamese were slightly less likely to report adequate physical activity. Thus, more research is needed to delineate the barriers and interventions needed to promote exercise among this population.

Cigarette smoking is another important risk factor for cardiovascular diseases. Smoking prevalence in the general male population of California have declined from $28.2 \%$ in 1985 to $17.0 \%$ in $2005 .{ }^{32}$ However, the prevalence among Vietnamese men in Santa Clara County, California, has barely declined, from $35 \%$ in $1996^{33}$ to $31.2 \%$ in $2001^{22}$ to $29.8 \%$ in this study. This slight decline has occurred despite the availability of a toll-free quitline with Vietnamese-language capability, multimedia campaigns in the Vietnamese language, and medications to treat nicotine addiction. ${ }^{34,35}$ Clearly, new approaches, which may have to be more directed and intensive, are needed to reduce smoking among men in this population. Efforts should also be made to maintain the low rates of smoking among Vietnamese-American women since there may be a rise in smoking with acculturation among Asian Americans. ${ }^{36}$

Vietnamese Americans may not meet the Healthy People 2010 recommendations for fruit and vegetable consumption (75\% with at least two daily servings of fruit and 50\% with at least three daily servings of vegetables). ${ }^{37}$ This finding is rather surprising, because the typical Vietnamese diet is high in carbohydrates and low in fat $^{38}$, and Vietnamese Americans report a strong preference for fruits and vegetables. ${ }^{39}$ Measurement problems may underlie this finding. Five of the six items in the questionnaire ask for "times" rather than "servings," and it is possible that Vietnamese Americans may eat more than one serving of fruit or vegetables at a time. It is important for future studies of nutrition among Vietnamese and Asian Americans to assess the best method to collect accurate dietary intake data.

Another problem identified by this study is the lack of knowledge of heart attack and stroke symptoms. Recognition of these symptoms is important, because early treatment can save lives and prevent morbidity. Only 59\% of Vietnamese Americans in this study knew that chest pain was a symptom for heart attack, compared to 95\% of Americans in the 2001 BRFSS. ${ }^{28}$ In our study, there was no differences in knowledge of symptoms between English-speaking and Vietnamesespeaking Vietnamese Americans. An educational campaign targeting Vietnamese Americans in both languages about the symptoms of heart attack and stroke may be needed. 
The findings in this report are subject to some limitations. Persons without telephones and those who used only cell phones were not included in the survey. Because estimates were based on self-reported data, the prevalence of certain chronic conditions might be under- or overestimated. Although most of the measures included in this report have high or moderate reliability and validity, ${ }^{40}$ they have not been evaluated in Vietnamese populations.

Our study shows that the self-reported prevalences of cardiovascular diseases are somewhat lower among Vietnamese Americans than among non-Hispanic whites. However, Vietnamese Americans have significant disparities in cardiovascular risk factors, such as physical inactivity and cigarette smoking among men, as well as in knowledge of heart attack and stroke symptoms. It is likely that, in the absence of change, the rates of adverse cardiovascular outcomes, such as heart attacks and strokes, will rise. The findings from this study underscore a need for further research into understanding the determinants of cardiovascular risk factors and into developing culturally appropriate interventions to address them in this understudied population.

Acknowledgement: This project was funded by the US Centers for Disease Control and Prevention under Cooperative Agreements U50/CCU917412 and U50/CCU922156. The findings and conclusions of the article are solely the responsibility of the authors and do not necessarily represent the views of the Centers for Disease Control and Prevention. A preliminary version of this data was presented at the annual meeting of the American Public Health Association in November 2007.

\section{Conflict of Interest: None disclosed.}

Corresponding Author: Tung T. Nguyen, MD; Vietnamese Community Health Promotion Project, Division of General Internal Medicine, Department of Medicine, University of California, San Francisco, Box 0320, UCSF, San Francisco, CA 94143, USA(e-mail: Tung.Nguyen @ucsf.edu).

\section{REFERENCES}

1. Reeves TJ, Bennett CE. The Asian and Pacific Islander Population in the United States. Washington, DC: U.S. Census Bureau; 2003. Current Population Reports P20-540.

2. U.S. Census Bureau. The American Community-Asians: 2004. The American Community Survey Reports. Washington, DC: U.S. Department of Commerce; 2007.

3. McPhee S, Jenkins C, Hung S, et al. Behavioral risk factor survey of Vietnamese-California, 1991. Morb Mortal Wkly Rep. 1992;41(5)69-72.

4. Jenkins CN, Le T, McPhee SJ, Stewart S, Ha NT. Health care access and preventive care among Vietnamese immigrants: do traditional beliefs and practices pose barriers? Soc Sci Med. 1996;43(7):1049-56.

5. McPhee SJ, Bird JA, Davis T, Ha NT, Jenkins CN, Le B. Barriers to breast and cervical cancer screening among Vietnamese-American women. Am J Prev Med. 1997;13(3):205-13.

6. McPhee SJ, Stewart S, Brock KC, Bird JA, Jenkins CN, Pham GQ. Factors associated with breast and cervical cancer screening practices among Vietnamese American women. Cancer Detection and Prevention. 1997;21(6):510-21.

7. Nguyen T, Vo PH, McPhee SJ, Jenkins CN. Promoting early detection of breast cancer among Vietnamese-American women. Results of a controlled trial. Cancer. 2001;91(1 Suppl):267-73.

8. McPhee SJ. Caring for a 70-year-old Vietnamese woman. JAMA. 2002;287(4):495-504.

9. Nguyen TT, McPhee SJ, Nguyen T, Lam T, Mock J. Predictors of cervical Pap smear screening awareness, intention, and receipt among Vietnamese-American women. Am J Prev Med. 2002;23(3):207-14.
10. Nguyen TT, McPhee SJ, Gildengorin G, et al. Papanicolaou testing among Vietnamese Americans: results of a multifaceted intervention. Am J Prev Med. 2006;31(1):1-9.

11. Nguyen TT, McPhee SJ, Bui-Tong $\mathbf{N}$, et al. Community-based participatory research increases cervical cancer screening among Vietnamese-Americans. J Health Care Poor Underserved. 2006;17(2 Suppl):31-54.

12. Mock J, McPhee SJ, Nguyen T, et al. Effective lay health worker outreach and media-based education for promoting cervical cancer screening among Vietnamese American women. Am J Public Health. 2007;97(9): 1693-700.

13. Miller BA, Kolonel LN, Bernstein L, et al. Racial/Ethnic Patterns of Cancer in the United States 1988-1992. NIH Publ. No. 96-4104. Bethesda, MD: National Cancer Institute; 1996.

14. Cockburn M, Deapen D, eds. Cancer Incidence and Mortality in California: Trends by Race/Ethnicity, 1988-2001. Los Angeles, California: University of Southern California; 2004.

15. National Center for Health Statistics. Health, United States 2005 Hyattsville, MD: U.S. Department of Health and Human Services; 2005

16. Ueshima H, Okayama A, Saitoh S, et al. Differences in cardiovascular disease risk factors between Japanese in Japan and Japanese-Americans in Hawaii: the INTERLIPID study. J Hum Hypertens. 2003;17 (9):631-9.

17. Singh GK, Miller BA. Health, life expectancy, and mortality patterns among immigrant populations in the United States. Can J Public Health. 2004;95(3):I14-21.

18. Pham TM, Rosenthal MP, Diamond JJ. Hypertension, cardiovascular disease, and health care dilemmas in the Philadelphia Vietnamese community. Fam Med. 1999;31(9):647-51.

19. Duong DA, Bohannon AS, Ross MC. A descriptive study of hypertension in Vietnamese Americans. J Community Health Nurs. 2001;18(1):1-11.

20. National Heart, Lung, and Blood Institute. Cardiovascular Risk in the Vietnamese Community: Formative Research from Houston, Texas. Bethesda, MD: U.S. Department of Health and Human Services; 2003.

21. McPhee SJ, Nguyen TT. Cancer, cancer risk factors, and communitybased cancer control trials in Vietnamese Americans. Asian Am Pac Isl J Health. 2000;81(1):8-31. Winter.

22. Rahman MM, Luong NT, Divan HA, et al. Prevalence and predictors of smoking behavior among Vietnamese men living in California. Nicotine Tob Res. 2005;7(1):103-9.

23. Koch-Weser S, Grigg-Saito D, Liang S, et al. Health status of Cambodian and Vietnamese Americans compared with that of all Asian Americans and the U.S. Population - - Analysis of data from the REACH 2010 Risk Factor Survey. Morbidity Mortality Weekly Reports. 2004;53 (33):760-4.

24. Giles WH, Tucker P, Brown L, et al. Racial and ethnic approaches to community health (REACH 2010): an overview. Ethn Dis. 2004;14(3 Suppl 1):S5-8. Summer.

25. Liao Y, Tucker P, Okoro CA, Giles WH, Mokdad AH, Harris VB. REACH 2010 Surveillance for Health Status in Minority Communities-United States, 2001-2002. MMWR Surveill Summ. 2004;53(6):1-36. Aug 27.

26. Mokdad AH, Stroup DF, Giles WH. Public health surveillance for behavioral risk factors in a changing environment. Recommendations from the Behavioral Risk Factor Surveillance Team. MMWR Recomm Rep. 2003;52(RR-9): 1-12. May 23.

27. Pate RR, Pratt M, Blair SN, et al. Physical activity and public health. A recommendation from the Centers for Disease Control and Prevention and the American College of Sports Medicine. JAMA. 1995;273(5):402-7.

28. Greenlund KJ, Keenan NL, Giles WH, et al. Public recognition of major signs and symptoms of heart attack: seventeen states and the US Virgin Islands, 2001. Am Heart J. 2004;147(6):1010-6. Jun.

29. Zhou BF. Effect of body mass index on all-cause mortality and incidence of cardiovascular diseases-report for meta-analysis of prospective studies open optimal cut-off points of body mass index in Chinese adults. Biomed Environ Sci. 2002;15(3):245-52.

30. Bei-Fan Z. Predictive values of body mass index and waist circumference for risk factors of certain related diseases in Chinese adults: study on optimal cut-off points of body mass index and waist circumference in Chinese adults. Asia Pac J Clin Nutr. 2002;11(Suppl 8):S685-93.

31. Lauderdale DS, Rathouz PJ. Body mass index in a US national sample of Asian Americans: effects of nativity, years since immigration and socioeconomic status. Int J Obes Relat Metab Disord. 2000;24(9):118894.

32. California Tobacco Control Section. Adult Smoking Prevalence. Sacramento, CA: California Department of Health Services; 2006. 
33. Jenkins CN, McPhee SJ, Le A, Pham GQ, Ha NT, Stewart S. The effectiveness of a media-led intervention to reduce smoking among Vietnamese-American men. Am J Public Health. 1997;87(6):1031-4. Jun.

34. Zhu SH, Anderson CM, Johnson CE, Tedeschi G, Roeseler A. A centralised telephone service for tobacco cessation: the California experience. Tob Control. 2000;9(Suppl 2):II48-55.

35. Tang H, Shimizu R, Chen MS Jr. English language proficiency and smoking prevalence among California's Asian Americans. Cancer. 2005; 104(12 Suppl):2982-8. Dec 15.

36. Chen X, Unger JB, Cruz TB, Johnson CA. Smoking patterns of AsianAmerican youth in California and their relationship with acculturation. $J$ Adolesc Health. 1999;24(5):321-8. May.
37. U.S. Department of Health and Human Services. Healthy People 2010. 2nd ed. With Understanding and Improving Health and Objectives for Improving Health, 2 vols. Washington, DC: U.S. Department of Health and Human Services; 2000.

38. Dien le N, Thang NM, Bentley ME. Food consumption patterns in the economic transition in Vietnam. Asia Pac J Clin Nutr. 2004;13(1):40-7.

39. Harrison GG, Kagawa-Singer M, Foerster SB, et al. Seizing the moment: California's opportunity to prevent nutrition-related health disparities in low-income Asian American population. Cancer. 2005; 104 (12 Suppl):2962-8.

40. Nelson DE, Holtzman D, Bolen J, Stanwyck CA, Mack KA. Reliability and validity of measures from the Behavioral Risk Factor Surveillance System (BRFSS). Soz Praventivmed. 2001;46(Suppl 1)S3-42. 